\title{
PROFIL GLUKOSA DARAH, LIPID DAN VISUALISASI PULAU LANGERHANS SEBAGAI IMUNOREAKTOR INSULIN DAN GLUKAGON PADA PANKREAS TIKUS (Rattus norvegicus) OBESITAS MENGGUNAKAN TEKNIK IMUNOHISTOKIMIA
}

\author{
Dela Ria Nesti ${ }^{1}$, Ahmad Baidlowi ${ }^{2}$ \\ 1,2Program Studi Kesehatan Hewan/Departemen Teknologi Hayati dan Veteriner/Sekolah Vokasi, Universitas Gadjah Mada, Indonesia \\ Email: 1delarianesti87@gmail.com, ${ }^{2}$ ahmad.baidlowi@mail.ugm.ac.id
}

\begin{abstract}
Obesity is not concerned as specific congenital disorder or derived lipid metabolism disorder recently, but more to body inability to handle the increase of nutrition intake caused by behavioral changes. Langerhans Islet is a section in the pancreas which play crucial role in producing and regulating metabolism hormones, insulin and glucagon. This research was conducted to observe blood glucose and lipid profile and to visualize Langerhans Islet in rat pancreas which were induced obesity and compared it with normal ones. Ten of male non-genetic obese four weeks old Winstar rats were divided into two groups, normal $(K)$ and induced with obesity $(O)$. Blood plasma samples were collected to determine blood glucose and blood lipid profile. Pancreas (regio splenic) samples were collected and fixated with Bouin solution, blocked by paraffin and cut with $5 \mu \mathrm{m}$ thickness. Histology preparats were stained with Hematoxylin-Eosin and Immunohistochemistry (IHC) is determined with Labeled Sterptavidin-Biotin (LSAB) method. Staining is act as visual detector with will be analyzed descriptively and quantitatively. The data of Obesity group showed that blood glucose level is $88.59 \pm 1.77 \mathrm{mg} / \mathrm{dl}$, blood cholesterol level is $160.62 \pm 3.52 \mathrm{mg} / \mathrm{dl}$, triglycerides level is $98.61 \pm 2.66 \mathrm{mg} / \mathrm{dl}$, HDL level is $44.68 \pm 2.25 \mathrm{mg} / \mathrm{dl}$ and LDL level is 67.51 1.81. Pancreas's topography in obese group spread into three regions, which are: gastrium, duodenum and lien. Langerhans Islet morphology shaped oval and polygonal also surrounded by fine filaments and blood capillary. Insulin and glucagon immunoreactive cell's morphology in obesity group shaped irregular polygonal with round/oval

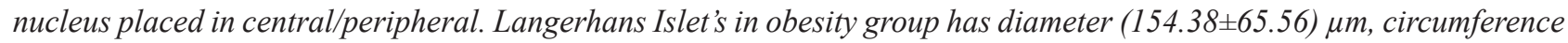
$(373,51 \pm 146,69) \mu \mathrm{m}$ and volume $3241105.96 \mu \mathrm{m} 3$. Obesity induced rat showed the increase in cholesterol level, triglycerides level, LDL level, blood glucose level and Langerhans Islet's diameter, volume and circumference compared to normal ones $(P<0.05)$. Decrease of $H D L$, topography and morphology of pancreas in obesity induced rat did't showed significant changes compared to normal ones.
\end{abstract}

Keywords: obesity, glucose, lipid, Langerhans islet, immunohistochemistry.

\section{PENDAHULUAN}

Obesitas mulai menjadi masalah kesehatan di seluruh dunia. Perubahan sosial dan transisi gizi pada negara-negara maju dan berkembang termasuk Indonesia telah mendorong epidemi obesitas selama beberapa dekade terakhir. Pertumbuhan ekonomi, modernisasi, urbanisasi, dan globalisasi pasar makanan adalah beberapa elemen yang telah memberikan kontribusi terhadap epidemi obesitas (Kanasaki dan Koya, 2011). Kondisi ini juga terjadi pada hewan kesayangan seperti anjing jenis Labrador retriever, Terrier cairn dan Beagles yang dilaporkan sering mengalami obesitas (Manens et al., 2012).

Gangguan hemostatis energi yang berasal dari predisposisi genetik bisa mempromotori obesitas (Martyn et al., 2008). Penelitian tentang pengaruh obesitas pada hewan genetic obese melalui mutasi gen seperti ob/ob mice, db/dbmouse, Zunker falfa rat dan BSB mouse sudah banyak dilakukan (Vicker et al., 2011; Slavin et al., 2010). Obesitas baru-baru ini tidak dianggap sebagai kelainan kongenital spesifik atau kelainan turunan terhadap metabolisme lipid, tetapi lebih kepada ketidakmampuan tubuh dalam mengatasi tingginya asupan nutrisi akibat perubahan gaya hidup (Martyn et al., 2008). Kalori yang berlebih diketahui menjadi salah satu promotor terjadinya obesitas. Pemberian diet tinggi lemak (50\%) dan karbohidrat (65\%) pada hewan non-genetic obese dapat mencerminkan pola asupan nutrisi sosial modern selama dua dekade terakhir yang memberikan kontribusi utama terhadap epidemi obesitas (Dourmashkin et al., 2005; Wang dan Liao, 2012). Diet lemak memberikan kontribusi yang signifikan terhadap berat badan, hiperfagia, dan penumpukan lemak di dalam tubuh. Pemberian diet tinggi lemak menyebabkan peningkatan sirkulasi leptin, insulin, trigliserida, dan glukosa yang berefek pada aktivitas lipoprotein lipase dalam jaringan lemak yang meningkatkan uptake lemak serta menurunkan pengeluaran energi, aktivitas nervus simpatetik dan oksidasi karbohidrat di otot. Kelebihan asupan karbohidrat juga berkontribusi menyebabkan obesitas dengan stimulasi sekresi insulin (Dourmashkin et al., 2005).

Pankreas merupakan campuran dari kelenjar eksokrin dan endokrin. Bagian eksokrin berfungsi untuk mensekresikan ion-ion, enzim, dan proenzim seperti tripsinogen, kimotripsinogen, karboksipeptidase, ribonuklease, deoksiribonuklease, lipase, dan amilase. Bagian endokrin menghasilkan homon insulin, glukagon, dan pankreas polipeptida yang erat 
kaitannya dalam pengaturan regulasi energi dalam tubuh (Junqueira dan Carneiro, 1992). Kadar glukosa yang berlebih di dalam darah menyebabkan pankreas mensekresikan insulin untuk menghambat kerja glukagon dalam menghasilkan glukosa, mendistribusikan glukosa ke jaringan otot, menginduksi proses lipogenesis dan uptake glukosa pada jaringan lemak, menghambat pembentukan glukosa oleh hepar serta mengirimkan rangsangan ke hipotalamus untuk menghambat anorexigenic system (Berridge, 2012; Elmquist, 2012). Miyaki et al. (1994) menyatakan bahwa pankreas tikus terletak di mesoduodenum dan terdiri dari bagian tubuh dengan lobus kanan dan kiri. Tubuh pankreas terletak di sepanjang bagian kranial dari duodenum. Lobus kanan diperluas sampai ke ligamentum duodenum, sedangkan lobus kiri memanjang kearah limpa. Elayat et al. (1995) mengungkapkan bahwa pankreas tikus dibagi menjadi beberapa regio yaitu duodenal dengan lobus dorsal dan ventral, regio gastric dan regio splenic (lien).

Endokrin pankreas (Pulau Langerhans) tersebar di seluruh pankreas. Pulau Langerhans tampak sebagai kelompok sel berbentuk bulat, pucat, dikelilingi serabut halus, tidak memiliki saluran, dengan banyak pembuluh darah untuk penyaluran hormon kelenjar pankreas (Johnson, 1993; Subowo, 1992; Tambajong, 1995). Pulau-pulau kecil sel endokrin ditemukan berselang-seling diantara sel eksokrin pankreas (Ganong, 1995; Subowo, 1992). Serabut retikuler halus mengelilingi setiap Pulau Langerhans dan memisahkannya dari eksokrin pankreas yang berdekatan. Sel-sel parenkim dan pembuluh darah di inervasi oleh serat saraf autonom (Junqueira dan Carneiro, 1992). Pulau Langerhans kebanyakan berdiameter 100-200 $\mu$ m. Pulau Langerhans merupakan kumpulan sel berbentuk ovoid, berukuran 76 x 0,2 $\mu$ m yang tersebar di seluruh pankreas (Ganong, 1995). Semua sel dalam Pulau berbentuk poligonal tidak beraturan dengan inti bundar di tengah, mitokondria kecil berbentuk batang dan aparatus golgi kecil (Leeson et al., 1996).

Insulin dan glukagon merupakan regulator utama dalam mengatur metabolisme energi. Insulin membantu mengontrol kadar glukosa dengan meningkatkan uptake glukosa di jaringan, stimulasi glikogenesis serta menghambat glikogenolisis dan glukoneogenesis. Insulin berperan dalam mempromotori lipogenesis, penyimpanan trigliserida, menginduksi sintesis protein di hepar dan otot serta meningkatkan pertumbuhan proliferasi sel pada kondisi obesitas. Glukagon berfungsi sebagai penyeimbang dan menjaga konsentrasi glukosa tetap normal dalam darah (Aronoff et al., 2004). Pengaruh obesitas pada pankreas tikus nongenetic obese yang diberi diet tinggi karbohidrat dan lemak perlu divisualisasikan ditingkat seluler melalui identifikasi morfologi, morfometri dan distribusi Pulau Langerhans, sel imunoreaktif insulin dan sel imunoreaktif glukagon.

Penelitian tentang obesitas menggunakan tikus genetik obesitas sebagai objek penelitian telah banyak dilakukan (Ikemoto et al., 1995). Mencit yang mengalami obesitas menunjukkan hiperplasia Pulau Langerhans, hipertropi Pulau Langerhans serta hiperplasia sel $\alpha, \beta$, dan $\delta$ (Tomita et al.,1992; Lindstrom, 2007; Slavin et al., 2010; Harishankar et al., 2011). Pemberian diet tinggi lemak pada tikus bunting beserta keturunan jantan dan betinanya sampai postnatal menunjukkan perubahan signifikan di Pulau Langerhans antara lain hiperplasia sel $\alpha$, sel $\beta$ dan peningkatan proliferasi sel asinus pada (Cerf et al., 2012). Penelitian yang menggambarkan pengaruh obesitas akibat diet tinggi lemak dan karbohidrat terhadap aktivitas sel penghasil insulin dan glukagon pada pankreas menggunakan tikus normal (nongenetic obese rat) belum dilaporkan.

Penelitian ini bertujuan untuk melihat profil glukosa darah, lipid dan memvisualisasikan Pulau Langerhans pada pankreas tikus yang diinduksi obesitas serta membandingkannya dengan tikus normal. Analisis data yang dihasilkan dapat bermanfaat untuk mengurangi resiko obesitas yang disebabkan oleh gangguan metabolik dan pengaruhnya terhadap hormon insulin dan glukagon.

\section{BAHAN DAN METODE PENELITIAN}

Hewan coba yaitu tikus putih (Rattus norvegicus) nongenetic obese, jantan, jenis wistar, umur 4 minggu dipisah dalam dua kelompok, yaitu kelompok kontrol dan obesitas dengan masing-masing kelompok berjumlah 5 ekor. Sampel plasma diambil dari darah segar (infraorbitalis) yang diberi Ethylene Diamine Tetraacetic acid (EDTA) dan disentrifus. Sampel organ berupa pankreas (regio splenic) diambil dari masing-masing hewan coba. Larutan fiksatif yang digunakan, yaitu larutan Bouin yang terdiri dari campuran formaldehid 37\%, asam pikrat, dan asam asetat glasial dengan perbandingan komposisi 25:75:5. Pewarnaan jaringan dengan Hematoksilin eosin menggunakan bahan meliputi larutan xilol, alkohol bertingkat (70\%, 80\% dan 90\% dan alkohol absolut), Haris hematoksilin, dan eosin.

Bahan yang digunakan dalam metode imunohistokimia adalah PBS (Posfat Buffer Saline), sitrat buffer, akuades, alkohol bertingkat (70\%, 80\% dan 90\% dan alkohol absolut), xilol, hematoksilin, antibodi primer mouse anti-insulin (1:1500; Abcam, USA), anti bodi primer rabbit anti-glucagon (1;1500; Cosmo Bio Co, Japan), backgound sniper (Biocare Medical, USA), antibodi sekunder Trekkie Universal Link (Biocare Medical, USA), TrekAvidin-HRP (Biocare Medical, USA), DAB, dan substrat (Biocare Medical, USA). Peralatan yang digunakan untuk masing-masing pewarnaan meliputi tissue cassete, gelas objek, mikropipet, tip, inkubator, refrigerator, waterbath, slide warmer, timbangan analitik, gelas ukur, erlenmeyer, magnetic stirrer, kertas saring, dan mikroskop cahaya yang dilengkapi dengan optilab. 


\subsection{Perlakukan terhadap Hewan Coba}

Kelompok obesitas diberi pakan secara ad libitum setiap hari selama 9 minggu dengan komposisi karbohidrat $47 \%$, protein $22 \%$ dan lemak $31 \%$ serta tambahan suspensi fruktosa dan kolesterol masing-masing $1 \%$ per berat badan yang dihomogenisasi dalam $2 \mathrm{ml} \mathrm{Na}$ CMC (Carboxyl Methyl Celulose). Suspensi fruktosa dan kolesterol diberikan sebagai aplikasi tambahan dari diet tinggi lemak dan karbohidrat.

Tikus kelompok obesitas dan kontrol dipuasakan selama 8 jam kemudian masing-masing diambil darahnya melalui sinus infraorbitalis. Sampel darah kemudian disimpan dalam tabung berisi EDTA 10\%, disentrifus selama 10 menit dengan kecepatan $4000 \mathrm{rpm}$ dan diambil plasmanya untuk melihat profil gula darah dan lipid.

\subsection{Pemeriksaan Kadar Gula Darah dan Lipid}

Pemeriksaan kadar glukosa darah dilakukan dengan metode Enzymatic Colorimetric Test GOD-PAP (Glucose Oxidase Para Aminophenazone). Metode Colorimetric Test GOD-PAP dilakukan dengan mencampurkan sampel plasma sebanyak $10 \mu \mathrm{l}$ dengan $1000 \mu \mathrm{l}$ reagen, diinkubasi selama 20 menit pada suhu ruang $\left(20-25^{\circ} \mathrm{C}\right)$, dan hasilnya dibaca menggunakan spektrofotometri dengan panjang gelombang 500nm.

Kadar trigliserida dihitung dengan Metode Enzymatic Colorimetric Test. Metode Enzymatic Colorimetric Test dilakukan dengan mencampurkan sampel plasma sebanyak $10 \mu 1$ dengan $1000 \mu 1$ reagen, kemudian diinkubasi selama 20 menit pada suhu ruang, dan hasilnya dibaca menggunakan spektrofotometri dengan panjang gelombang $546 \mathrm{~nm}$.

High Density Lipoprotein (HDL) dihitung menggunakan Metode Presipitasi. Sampel plasma sebanyak $200 \mu 1$ dicampur dengan 500 $\mu 1$ HDL diluted selama 10 menit, kemudian disentrifus selama 10 menit dengan kecepatan 4000rpm pada suhu ruang. Supernatan sebanyak $100 \mu$ dicampur dengan reagen dan diinkubasi selama 10 menit pada suhu ruang. Hasil penghitungan dibaca menggunakan spektofotometri dengan panjang gelombang $546 \mathrm{~nm}$.

Low Density Lipoprotein (LDL) dihitung menggunakan Metode Presipitasi. Sampel plasma sebanyak $100 \mu 1$ dicampur dengan $1000 \mu \mathrm{l}$ precipitating reagent, diinkubasi selama 10 menit, dan disentrifus selama 10 menit dengan kecepatan $4000 \mathrm{rpm}$. Supernatan diambil sebanyak $100 \mu$, dicampur dengan reagen, diinkubasi selama 10 menit pada suhu ruang, dan hasilnya dibaca menggunakan spektrofotometri dengan panjang gelombang $546 \mathrm{~nm}$.

Total kolesterol dihitung dengan Metode Enzymatic Colorimetric Test CHOD-PAP (Cholesterol Oxidase Para Aminophenazone). Metode Enzymatic Colorimetric Test CHOD-PAP dilakukan dengan mencampur sampel plasma sebanyak $10 \mu \mathrm{l}$ dengan $1000 \mu \mathrm{l}$ reagen, kemudian diinkubasi selama 20 menit pada suhu ruang, dan hasilnya dibaca menggunakan spektrofotometri dengan panjang gelombang $546 \mathrm{~nm}$.

\subsection{Koleksi Sampel dan Preparasi Jaringan Pankreas}

Tikus kontrol dan obesitas dieutanasi menggunakan cloroform. Tikus dinekropsi, diambil pankreasnya, difiksasi pada larutan Bouin selama 24 jam, kemudian diganti dengan larutan alkohol 70\% untuk disimpan sampai pemrosesan jaringan dilakukan. Sampel jaringan pankreas selanjutnya dipotong dengan ukuran 3 x 3 mm dan dimasukkan ke dalam tissue cassete (masing-masing diberi label). Tahap awal pemrosesan jaringan berupa dehidrasi yang dimulai dengan mencuci jaringan (dalam tissue cassete) di air mengalir selama 60 menit dan selanjutnya jaringan direndam pada alkohol 70\%, alkohol 80\%, alkohol 90\%, alkohol absolut I, absolut II, absolut III, secara bertahap masingmasing selama 60 menit. Clearing dilakukan dengan merendam jaringan pada larutan xilol I, xilol II dan xilol III secara bertahap masing-masing selama 20 menit.

Tahap infiltrasi parafin dan pengeblokan bertujuan untuk memasukkan parafin ke dalam ruang sel sehingga membuat jaringan memiliki konsistensi kuat yang diperlukan untuk pemotongan. Proses infiltrasi parafin diawali dengan mencairkan parafin pada 4 gelas ukur di dalam inkubator $\left(58^{\circ}-60^{\circ}\right)$ selama 24 jam. Jaringan dimasukkan ke dalam parafin cair I, II, III, yang ada dalam inkubator masing-masing selama 1 jam. Proses pengeblokan dilakukan di atas tungku penghangat agar parafin tetap cair selama parafin dari gelas ke IV dimasukkan ke dalam cetakan. Jaringan diambil dari parafin cair gelas ke III dan dimasukkan ke dalam cetakan dengan letak yang sesuai, setelah itu blok didinginkan dan disimpan di refrigerator. Blok parafin yang berisi potongan jaringan selanjutnya dilepas dari cetakan dan diberi pegangan. Mikrotom disiapkan dan blok parafin dipotong dengan ketebalan 5-6 $\mu \mathrm{m}$ secara serial (1-7 potongan jaringan). Hasil potongan blok dimasukkan pada waterbath berisi air dan gelatin masing-masing direkatkan pada obyek glass (coated slide) yang berbeda. Potongan I-IV berturut-turut diwarnai dengan Hematoksilin Eosin dan imunohistokimia dengan antibodi primer mouse anti-insulin dan abbit anti-glukagon. 


\subsection{Pewarnaan Hematoksilin Eosin (HE)}

Pewarnaan HE diawali dengan tahap deparafinisasi dengan merendam preparat jaringan pada xilol bertingkat (xilol I, xilol II dan xilol III) masing-masing selama 5 menit. Slide yang berisi preparat jaringan direndam pada alkohol bertingkat (alkohol absolut I, alkohol absolut II, alkohol absolut III, alkohol 90\%, alkohol 80\%, dan alkohol 70\%) masing-masing selama 5 menit. Preparat jaringan kemudian direndam pada larutan Haris hematoksilin selama 5 menit, dicuci dengan air mengalir 10 menit kemudian direndam pada larutan eosin selama 25 menit. Preparat jaringan didehidrasi pada alkohol bertingkat (alkohol 70\%, 80\%, 90\%, alkohol absolut I, alkohol absolut II dan alkohol absolut III) masing-masing selama 30 detik dan di clearing dengan xilol I, xilol II, xilol III masing-masing selama 10 menit. Tahap akhir yaitu mounting dengan cover sliped dan entelan.

\subsection{Pewarnaan Imunohistokimia}

Pada pewarnaan imunohistokimia proses pertama yang dilakukan adalah deparafinisasi dan rehidrasi sama seperti pada pewarnaan HE. Preparat jaringan selanjutnya direndam pada aquades selama 10 menit dan dilanjutkan dengan pencucian menggunakan PBS $0,01 \mathrm{M}(\mathrm{pH} 7,4)$ sebanyak $3 \mathrm{x} / 5$ menit. Aktivitas peroksidase endogen pada jaringan dihambat menggunakan $3 \% \mathrm{H}_{2} \mathrm{O}_{2}$ dalam akuades selama 30 menit. Preparat jaringan kemudian dicuci menggunakan PBS 0,01 M (pH 7,4) sebanyak $3 \mathrm{x} / 5$ menit. Antigen retrievel dilakukan dengan merendam preparat jaringan pada sitrat buffer mendidih 1 menit dan dibiarkan sampai dingin pada suhu ruang selama 60 menit. Preparat jaringan kemudian dicuci menggunakan PBS $0,01 \mathrm{M}(\mathrm{pH} 7,4)$ sebanyak 3x/5menit. Preparat jaringan diinkubasi dengan backgound sniper selama 15 menit pada suhu ruang untuk mencegah terjadinya pewarnaan yang tidak spesifik. Inkubasi antibodi primer (Mouse anti-insulin dan Rabbit anti-glucagon) dilakukan dengan cara ditetesi pada jaringan dan dibiarkan semalaman (over night) pada suhu $4^{\circ} \mathrm{C}$. Preparat jaringan kemudian dicuci menggunakan PBS 0,01 M (pH 7,4) sebanyak 3x/5menit. Antibodi sekunder diinkubasi menggunakan Trekkie Universal Link pada suhu ruang selama 30 menit yang dilanjutkan dengan pencucian menggunakan PBS $0,01 \mathrm{M}(\mathrm{pH} 7,4)$ sebanyak $3 \mathrm{x} / 5$ menit. Preparat jaringan selanjutnya ditetesi menggunakan TrekAvidin-HRP pada suhu ruang selama 10 menit sebagai indikator ikatan antigen, antibodi primer dan sekunder serta pencucian menggunakan PBS 0,01 M (pH 7,4) sebanyak 3x/5menit.

Ikatan antigen dan antibodi dapat diwarnai dengan campuran larutan DAB dan substrat (4 $\mu 1 \mathrm{DAB}+96 \mu 1$ substrat) dibiarkan selama 1 menit pada suhu ruang. Preparat jaringan kemudian dicuci dengan aquades 10 celup, direndam pada larutan hematoksilin selama 30 detik, dicuci dengan air mengalir selama 5 menit, dan dilanjutkan dengan tahap dehidrasi dan penjernihan sama seperti pada pewarnaan HE. Tahap akhir preparat jaringan yang sudah terwarnai di mounting menggunakan entelan dan ditutup dengan cover sliped. Hasil pewarnaan diamati menggunakan mikroskop cahaya yang dilengkapi dengan optilab.

\subsection{Pewarnaan Imunohistokimia}

Kadar glukosa darah, trigliserida, HDL, LDL, dan total kolesterol dihitung menggunakan Persamaan 1.

$$
\frac{\text { Nilai pembacaan fotometrik sampel }}{\text { Nilai pembacaan fotometrik kontrol }} \text { X Konsentrasi standar (mg/dl) }
$$

Topografi anatomi dan histologi pankreas dianalisa menggunakan metode deskriptif dan kuantitatif. Metode deskriptif digunakan untuk menjelaskan topografi pankreas, morfologi Pulau Langerhans dan morfologi sel IR insulin dan glukagon. Metode kuantitatif dilakukan untuk mengetahui morfometri meliputi diameter, keliling dan volume Pulau Langerhans. Pengukuran diameter sel, keliling Pulau Langerhans, dan jumlah sel menggunakan Program Software Optilab ${ }^{\circledR}$ Image RasterV2.1 dengan kalibrasi yang sudah disesuaikan. Volume Pulau Langerhans dihitung sesuai Persamaan 2.

$$
\text { Volume }=4 / 3 \pi \times(\text { Diameter } / 2)^{3}
$$

\section{HASIL DAN PEMBAHASAN \\ 3.1 Profil Glukosa Darah}

Hasil pengukuran rata-rata kadar glukosa darah kelompok obesitas $(161,43 \pm 7,61)$ lebih tinggi dibandingkan dengan kontrol $(88,59 \pm 1,77)(\mathrm{P}<0,01)($ Tabel 1). 
Tabel 1. Profil lipid dan glukosa plasma kelompok tikus obesitas dan kontrol (n=5)

\begin{tabular}{lcc}
\hline \multicolumn{1}{c}{ Karakteristik } & Kelompok obesitas & Kelompok kontrol \\
\hline Total kolesterol (mg/dl)a & $160,62 \pm 3,52$ & $108,84 \pm 4,08$ \\
Trigliserida (mg/d')a & $98,61 \pm 2,66$ & $70,03 \pm 3,02$ \\
HDL (mg/dl)c & $44,68 \pm 2,25$ & $44,92 \pm 2,42$ \\
LDL (mg/dl)a & $67,51 \pm 1,81$ & $51,77 \pm 2,44$ \\
Glukosa (mg/dl)a & $161,43 \pm 7,61$ & $88,59 \pm 1,77$ \\
\hline
\end{tabular}

Keterangan: HDL (High Density Lipoprotein), LDL (Low Density Lipoprotein)

Nilai merupakan mean \pm standar deviasi

${ }^{a}$ Nilai sangat signifikan $(\mathrm{P}<0,01)$

'Nilai tidak signifikan $(\mathrm{P}>0,05)$

Longmire dan Maclaren (2007) mengemukakan bahwa pada kondisi obesitas akan terjadi gangguan toleransi glukosa. Peningkatan asam lemak bebas dan gliserol melalui vena porta akibat lipolisis, akan berakibat pada peningkatan oksidasi asam lemak bebas di otot dan hepar yang akhirnya menurunkan intake glukosa di otot sehingga asam lemak bebas digunakan sebagai sumber energi alternatif. Glukosa yang tidak digunakan akan tetap berada pada pembuluh darah sehingga kadarnya tinggi dalam sirkulasi.

\subsection{Profil Lipid}

Profil lipid kelompok obesitas dan kontrol diukur dari plasma masing-masing kelompok yang sudah dipuasakan selama 8 jam. Kelompok obesitas menunjukkan nilai rata-rata total kolesterol $(160,62 \pm 3,52) \mathrm{mg} / \mathrm{dl}$ lebih tinggi dibandingkan kontrol $(108,84 \pm 4,08) \mathrm{mg} / \mathrm{dl}(\mathrm{P}<0,001)$. Kadar trigliserida kelompok obesitas $(98,61 \pm 2,66) \mathrm{mg} / \mathrm{dl}$ juga lebih tinggi dibandingkan kontrol $(70,03 \pm 3,02) \mathrm{mg} / \mathrm{dl}(\mathrm{P}<0,05)$ (Tabel 1).

Obesitas pada penelitian ini diinduksi dari pemberian pakan diet tinggi lemak berupa soybean oil dan lemak babi (Tabel 2) yang disertai dengan penambahan kolesterol 1\%/BB dan diberikan secara peroral menggunakan sonde setiap harinya. Guilherme et al. (2008) mengungkapkan bahwa kadar kolesterol dan trigliserida di dalam darah bersumber dari makanan, biosintesis di hepar, usus, korteks adrenal, lemak, dan jaringan reproduktif. Obesitas dapat menyebabkan terjadi perbesaran dan peningkatan jumlah sel lemak akibat tingginya mobilisasi lipid dan penyimpanan trigliserida di dalam sel. Hipertropi adiposit akan disertai dengan sekresi MCP-1 dalam jumlah berlebih yang dapat memicu infiltrasi makrofag ke dalam adiposit. Makrofag akan mensekresikan TNF- $\alpha$ dan IL1 $\beta$ yang menyebabkan disfungsi adiposit sehingga terjadi lipolisis dan penurunan penyimpanan trigliserida. Peningkatan lipolisis dan penurunan penyimpanan trigliserida menyebabkan peningkatan kadar asam lemak bebas dan trigliserida dalam darah.

Kelompok obesitas menunjukkan nilai LDL lebih tinggi $(67,51 \pm 1,81) \mathrm{mg} / \mathrm{dl}$ dibandingkan kontrol $(51,77 \pm 2,44) \mathrm{mg} /$ dl $(\mathrm{P}<0,01)$ (Tabel 1). Low Density Lipoprotein merupakan lipoprotein pengangkut kolesterol terbesar untuk disebarkan ke seluruh endotel jaringan perifer dan pembuluh darah. LDL merupakan metabolit dari VLDL yang mudah menempel pada endotel dan dapat menyebabkan penumpukan lemak dan penyempitan pembuluh darah (Guyton, 1994). Tingginya kadar kolesterol pada kondisi obesitas akan diikuti dengan peningkatan LDL dalam aliran darah.

Kadar HDL pada kelompok obesitas lebih rendah $(44,68 \pm 2,25) \mathrm{mg} / \mathrm{dl}$ dibandingkan dengan kontrol $(44,92 \pm 2,42) \mathrm{mg} /$ dl ( $>>0,05)$ (Tabel 1). High Density Lipoprotein memiliki 50\% lipoprotein yang berfungsi untuk mengangkut kolesterol bebas pada jaringan perifer ke reseptor HDL di hepar untuk dikatabolisme menjadi apoprotein, fosfolipid, kolesterol, dan trigliserida yang dieksresikan melalui empedu sehingga penimbunan kolesterol pada jaringan perifer akan berkurang. Kadar kolesterol yang tinggi pada kondisi obesitas menyebabkan berkurangnya jumlah HDL dalam aliran darah (Heslet, 2002). Kelompok obesitas pada penelitian ini tidak menunjukkan penurunan LDL yang signifikan dibandingkan kontrol. Peningkatan kadar kolesterol pada kelompok obesitas masih bisa ditoleransi oleh fungsi HDL sebagai transporter sehingga kadar HDL belum terlalu rendah.

\section{Topografi Pankreas}

Pankreas tikus kelompok obesitas dan kontrol masing-masing melekat pada tiga lokasi, yaitu pankreas yang menempel pada gastrium, duodenum, dan lien. Pankreas memiliki bentuk menyerupai jaringan lemak dan menyebar diantara gastrium, duodemun, dan lien sehingga sulit untuk diukur. Pemeriksaan histologi jaringan menggunakan pankreas area splenic (Gambar 1). Data yang menyebutkan adanya perbedaan topografi anatomi pankreas tikus obesitas dibandingkan tikus normal belum dipublikasikan. Miyaki et al. (1994) dan Elayat et al. (1995) menyebutkan lokasi pankreas tikus normal terletak di mesoduodenum dengan lobus kanan dan kiri yang memanjang ke arah limpa dan gastrium. Lokasi limpa merupakan lokasi yang paling banyak terdapat Pulau Langerhans yang diikuti dengan sel IR insulin dan glukagonnya. 

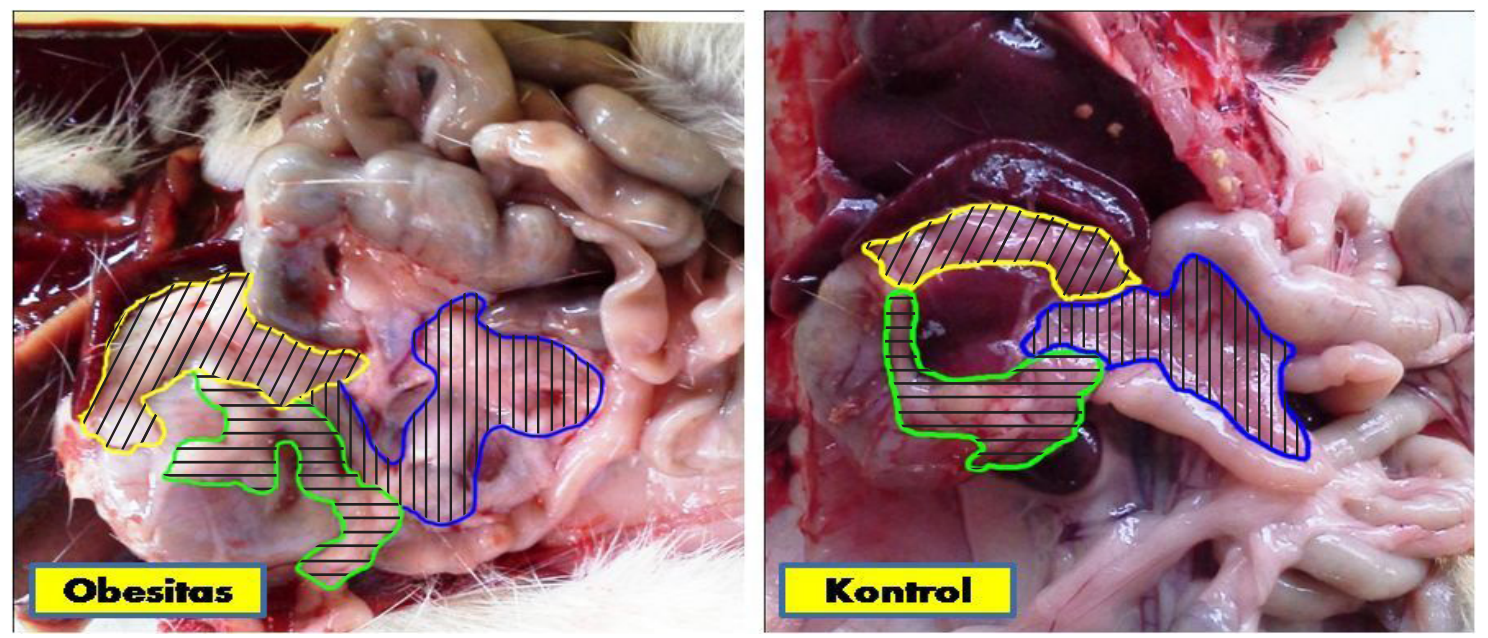

Gambar 1. Topografi pankreas kelompok obesitas dan kontrol. Pankreas kelompok obesitas dan kontrol tidak menunjukkan perbedaan bentuk dan lokasi yang bermakna karena menyerupai jaringan lemak sehingga sulit untuk diukur.

Keterangan:

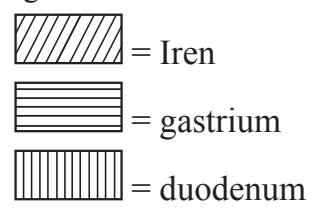

\section{Morfologi dan Morfometri Pulau Langerhans}

Pulau Langerhans merupakan bagian endokrin dari pankreas. Pulau Langerhans kelompok obesitas dan kontrol masing-masing memperlihatkan bentuk Pulau Langerhans yang bervariasi yaitu bulat, oval, dan poligonal. Setiap Pulau Langerhans dikelilingi oleh serabut halus yang membatasi area endokrin dan eksokrin (sel asinus) serta kapiler darah yang akan menyalurkan hormon (Gambar 2). Johnson (1993), Subowo (1992), dan Tambajong (1995) mengungkapkan bahwa Pulau Langerhans terlihat sebagai kelompok sel berbentuk bulat, pucat, dikelilingi serabut halus, tidak memiliki saluran dengan banyak pembuluh darah untuk penyaluran hormon kelenjar pankreas. Junqueira \& Carneiro (1992) menambahkan, serabut retikuler halus mengelilingi setiap Pulau Langerhans dan memisahkannya dari eksokrin pankreas yang berdekatan.
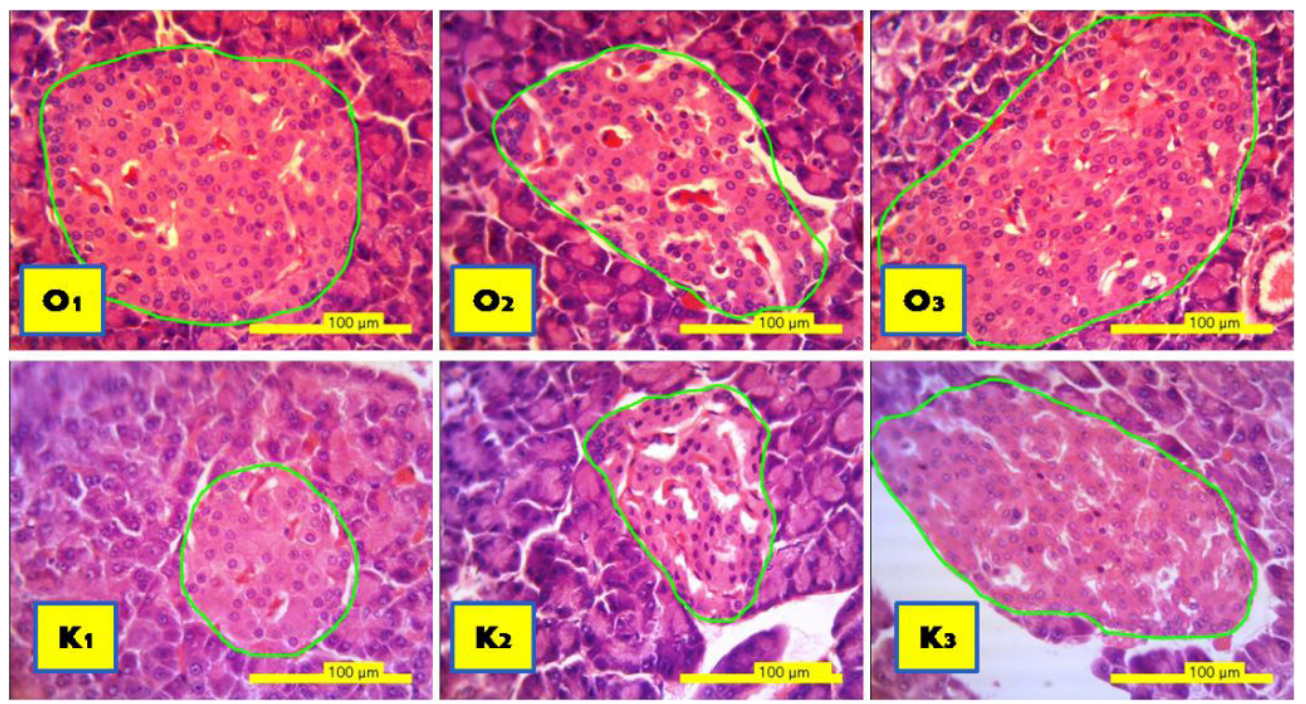

Gambar 2. Morfologi Pulau Langerhans kelompok obesitas dan kontrol. Bentuk Pulau Langerhans kelompok obesitas dengan kontrol tidak menunjukkan perbedaan yang bermakna yaitu sama-sama memilki bentuk bulat, oval, dan poligonal. Pulau Langerhans kelompok obesitas berbentuk bulat (O1), poligonal (O2), dan oval (O3), Pulau Langerhans kelompok kontrol berbentuk bulat (K1), poligonal (K2), dan oval (K3). 
Tabel 2. Morfometri Pulau Langerhans pada tikus obesitas dan kontrol (n=5)

\begin{tabular}{lcc}
\hline \multicolumn{1}{c}{ Aspek } & Obesitas & Kontrol \\
\hline Diameter Pulau Langerhans $^{\mathrm{a}}$ & $154,38 \pm 65,56$ & $116,52 \pm 52,35$ \\
Keliling Pulau Langerhans $^{\mathrm{a}}$ & $373,51 \pm 146,69$ & $286,79 \pm 116,67$ \\
Volume Pulau Langerhans $^{\mathrm{b}}$ & $3241105,96 \pm 684976,03$ & $1395370,99 \pm 198726,13$ \\
\hline
\end{tabular}

Keterangan: Nilai \pm standar deviasi

${ }^{a}$ Nilai sangat signifikan $(\mathrm{P}<0,01)$

${ }^{b}$ Nilai signifikan $(\mathrm{P}<0,05)$

Morfometri Pulau Langerhans menunjukkan diameter rata-rata Pulau Langerhans kelompok obesitas $(154,38 \pm 65,56)$ $\mu \mathrm{m}$ lebih besar dibandingkan dengan kontrol $(116,52 \pm 52,35) \mu \mathrm{m}(\mathrm{P}<0,01)$, volume rata-rata Pulau Langerhans kelompok obesitas $\left(3241105,96 \mu \mathrm{m}^{3}\right)$ lebih besar dibandingkan kontrol $\left(1395370,99 \mu \mathrm{m}^{3}\right)(\mathrm{P}<0,05)$, keliling Pulau Langerhans kelompok obesitas $(373,51 \pm 146,69) \mu \mathrm{m}$ lebih besar dibandingkan kontrol $(286,79 \pm 116,67) \mu \mathrm{m}(\mathrm{P}<0,01)($ Tabel 2).

Lindstrom (2007) mengungkapkan bahwa pada kondisi obesitas, mencit ob/ob yang genetik obesitas dengan karakter hiperfagia, hiperglikemia, dan hiperinsulinemia menunjukkan peningkatan ukuran Pulau Langerhans pankreas. Korelasi positif antara level hiperglikemia dengan replikasi sel di Pulau Langerhansobese-hyperglicemic mice dan reagregasi morfologi Pulau Langerhans ob/ob mice tergantung pada konsentrasi glukosa. Dor et al. (2004) menyebutkan bahwa Pulau langerhans dapat terbentuk melalui proliferasi sel endokrin yang berdiferensiasi, stem sel yang tidak terdiferensiasi (Bonner dan Sharma, 2002) atau neogenesis dari duktus pankreatikus (Bonner et al., 2004). Neogenesis merupakan proliferasi dan diferensiasi sel progenitor yang menentukan jumlah sel $\beta$ saat kelahiran. Sebagian kecil siklus sel $\beta$ masih dapat terus berkembang bila dibutuhkan sebagai mekanisme kompensasi tehadap peningkatan kebutuhan insulin. Stimulasi faktor eksternal seperti pancreatectomy, diet treatment, gejala awal terjadinya diabetes mellitus dapat berkontribusi meningkatkan regenerasi postnatal neogenesis Pulau Langerhans (Tse et al., 1997).

Sel IR insulin dan glukagon kelompok obesitas memiliki bentuk sel yang sama dengan kelompok kontrol, yaitu berbentuk poligonal tidak beraturan dengan inti bulat/oval dan terletak di sentral/perifer (Gambar 3).

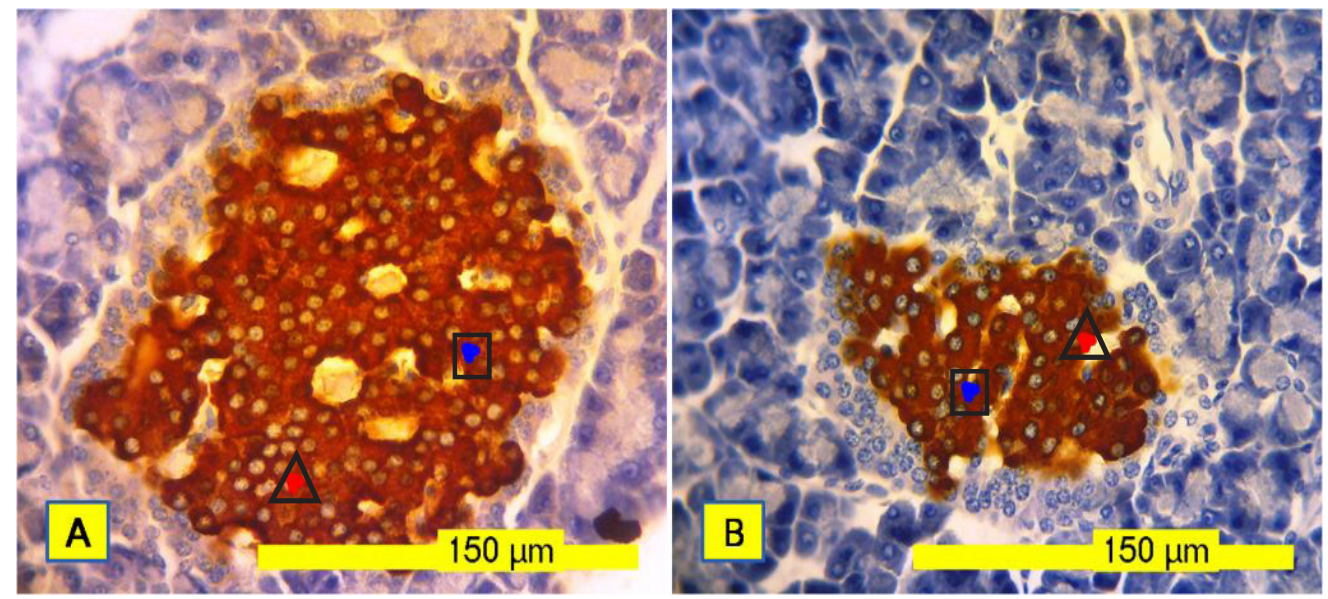

Gambar 3. Bentuk sel, bentuk nucleus, dan letak nukleus sel IR insulin kelompok obesitas dan kontrol.

Kelompok obesitas (A) dan kontrol (B) sama-sama menunjukkan bentuk sel poligonal dengan nukleus bulat (persegi) atau oval (segitiga) dan terletak di tengah atau perifer.

Pemberian diet tinggi karbohidrat dan lemak yang diberikan pada tikus nongenetically obese selama 9 minggu dapat menginduksi obesitas yang berdampak pada perubahan profil glukosa darah, lipid serta morfologi dan morfometri Pulau Langerhans.

\section{KESIMPULAN}

Tikus yang diinduksi obesitas menunjukkan peningkatan nilai total kolesterol, kadar trigliserida, LDL, glukosa, diameter Pulau Langerhans, volume Pulau Langerhans dan keliling Pulau Langerhans dibandingkan dengan kontrol $(\mathrm{P}<0,05)$. Penurunan kadar HDL, topografi, dan morfologi pankreas tikus yang diinduksi obesitas tidak menunjukkan perubahan yang signifikan dibandingkan dengan kontrol. 


\section{DAFTAR PUSTAKA}

Aronoff, S.L., Berkowiz, K., Shreiner, B., \& Want, L. (2004). Glucose Metabolism and Regulation: Beyond Insulin and Glucagon. Pharmaceuticals, Inc., 9360 Towne Centre Drive, San Diego, CA 92121. Diabetes Spectrum, 17, 183-190.

Berridge, M.J. (2012). Cell Signalling Biology Module 7. Portland Press Limited. www.cellsignallingbiology.org Accessed 26.02.14

Bonner, W.S., \& Sharma, A. (2002). Pancreatic Stem Cell. Journal Pathology, 197, 519-526.

Bonner, W.S., Toschi, E., Inada, A., Reitz, P., Fonseca, S.Y., Aye, T., \& Sharma, A. (2004). The Pancreatic Ductal Epithelium as a Potential Pool of Progenitor Cell. Pediatric Diabetic, 5, 16-22.

Cerf, E.M., Chapman, C.S., \& Louw, J. (2012). High-fat progamming of hyperglycemia, hyperinsulinemia, insulin resisten, hyperleptinemia, and altered islet architechture in 3-month-old Wistar Rat. ISRN Endocrinology, 1-8.

DiaSys Diagnostic System GmBh, Holzheim Germany. (2008).

Dor, Y., Brown, J., \& Martinez, O.I. (2004). Adult Pancreatic Beta-cell are Formed by Self-duplication rather than Stemcell Diferentiation. Nature, 429, 41-46.

Dourmashkin, J.T., Chang, G.Q., Gayles, E.C., Hill, J.O., Julien, C., \& Leibowitz, S.F. (2005). Different Forms of Obesity as a Function of Diet Composition. International Journal of Obesity; 1-11.

Droomers, M., Gross, R., \& Schultin, K.W. (1995). High Socio- Economic Class Preschool Children from Jakarta, Indonesia Are Taler And Heavier Than NCHS Reference Population. European Journal of Clinical Nutrition, 49, 740-744.

Elayat, A.A., Nanggar, M.M., \& Tahir, M. (1995). An Immunocytochemical and Morphometric Study of Rat Pancreatic Islet. Journal of Analytical Chemistry, 186, 629-637.

Elmquist, J.K., \& Scherer, P.E. (2012). Neuroendocrine and Endocrine Pathway of Obesity. The Journal of the American Medical Association, 308, 1070-1071.

Ganong, W.F. (1995). Fisiologi Kedokteran. (14 hed). Jakarta: Penerbit Buku Kedokteran EGC, (313-314).

Guiherme, A., Virbasius, J.V., Puri, V., \& Czech, M.P., (2008). Adipocyte Dysfunction Linking Obesity to Insulin Resisten and Type 2 Diabetes. Molecular Cell Biology, 368-370.

Harishankar, N., Kumar, P.U., Sesikeran, B., \& Giridharan, N. (2011). Obesity Associated Pathothysiological and Histological Changes in WNIN Obese Mutant Rats. The Indian Journal of Medical Research, 134, 330-340.

Heslet, L., (2002). Kolesterol. Penerjemah: Anton Adiwiyoto. Cetakan VII. Jakarta: Penerbit Megapoint, (63-68).

Ikemoto, S., Tomson, P.S., Takahasi, M., Itakura, H., Lane, M.D., \& Ezaki, O. (1995). High Fat Diet-Unduce Hyperglycemia: Prevention Buy Low Level Expression of a Glucose Transporter (GLUT 4) Mini Gene In Trangenic Mice. Science USA, 92, 3096-3099.

Johnson, K.E. (1993). Histology and Cell Biology. Cetakan I. Jakarta: Penerbit Binarupa aksara, (311-315).

Junqueira, L.C., \& Carneiro, J. (1992). Histologi Dasar. Cetakan III. Jakarta: Penerbit Buku Kedokteran EGC, (430-435).

Kanasaki, K., \& Koya, D. (2011). Biology of Obesity: Lesson from Animal Models of Obesity. Journal Biomed Biotechnology, 1-11.

Lesson, C.R., Leeson, T.S., \& Paparo, A.A. (1996). Histologi. Cetakan V. Jakarta: Penerbit Buku Kedokteran EGC, (380-383).

Lindstrom, P. (2007). The Phisiology of Obese-Hyperglycemic Mice (ob/ob Mice). The Scientific World Journal, 7, 666-685.

Longmire B.E., \& Maclaren N.K., (2007). Assesment of Child and Adolescent Overweight and Obesity. Pediatric, 120, 193-228.

Manens, J., Bolognin, M., Bernaerts, F., \& Diez, M.N.K. (2012). Effects of obesity on lung function and airway reactivity in healthy dogs. The Veterinary Journal, 193, 217-221.

Martyn, J.J.A., Kaneki, M., \& Yasuhara, S. (2008). Obesity-Induced Insulin Resisten and Hyperglycemia: Etiological Factor and Molecular Mechanisms. Anesthesiology, 109, 137-148. 
Miyaki, T., Nakama, K., Akimoto, T., Kitoh, J., \& Ito, H. (1994). Goss Morfology of the Pancreas and Distribution of Pancreas Duct in Rat. Jikken Dobutsu, 43, 257-260.

Slavin, B.G., Zarow, C., Warden, C.H., \& Fisler, J.S. (2010). Histological, Immunocytochemical and Morphometrical Analyses of Pancreatic Islet in BSB Mouse Model of Obesity. The Anatomical Record, 293, 108-116.

Subowo. (1992). Histologi Umum. Cetakan II. Jakarta: Penerbit Bumi Aksara, (38-39).

Tambajong, J. (1995). Sinopsis Histologi. Cetakan I. EGC. Jakarta, (138-141).

Tomita, T., Doull, V., Pollock, H.G., \& Krizsan, D. (1992). Pankreas Islet of Obese Hyperglycemic Mice Ob/Ob. Publication medical, 367-375.

Tse, O.E., Gregoire, F.M., Reusens, B., Remacle, C., Hoet, J.J., Jhonson, P.R., \& Stern, J.S. (1997). Changes of Islet Size and Islet Size Distribution Resulting from Protein-Malnutrition in Lean ( $\mathrm{Fa} / \mathrm{Fa}$ ) and Obese (fa/fa) Zucker Rats. Obesity Research, 5, 563-671.

Vicker, P.S., Jackson, H.C., \& Cheetham, S.C. (2011). Review the Utility of Animal Model to Evaluate Novel Anti-Obesity Agents. British Journal of Pharmacology, 164, 1248-1262.

Wang, C.Y., \& Liao, J.K. (2012). A Mouse Model of Diet-Induced Obesity and Insulin Resistance. Methods Molecular Biology, 821, 421-433. 